Article

\title{
Low-Temperature Plasma Nitriding for Austenitic Stainless Steel Layers with Various Nickel Contents Fabricated via Direct Laser Metal Deposition
}

\author{
Shinichiro Adachi *(D), Motoo Egawa, Takuto Yamaguchi and Nobuhiro Ueda \\ Research Division of Metal Finishing and Analysis, Osaka Research Institute of Industrial Science and \\ Technology, Ayumino 2-7-1, Izumi 594-1157, Japan; egawa@tri-osaka.jp (M.E.); t_yamaguchi@tri-osaka.jp (T.Y.); \\ ueda@tri-osaka.jp (N.U.) \\ * Correspondence: shinadachi@tri-osaka.jp; Tel.: +81-725-51-2648; Fax: +81-725-51-2749
}

Received: 24 March 2020; Accepted: 4 April 2020; Published: 7 April 2020

check for updates

\begin{abstract}
In this study, low-temperature plasma nitriding is applied to austenitic stainless steels at temperatures below $450{ }^{\circ} \mathrm{C}$. This enhances the wear resistance of the steels with maintaining corrosion resistance, by producing expanded austenite (known as the S-phase), which dissolves excessive nitrogen. Austenitic stainless steels contain nickel, which has the potential to play an important role in the formation and properties of the S-phase. In this experiment, austenitic stainless steel layers with different nickel contents were processed using direct laser metal deposition, and subsequently treated using low-temperature plasma nitriding. As a result, the stainless steel layers with high nickel contents formed the S-phase, similar to the AISI 316L stainless steel. The thickness and Vickers hardness of the S-phase layers varied with respect to the nickel contents. Due to lesser chromium atoms binding to nitrogen, the chromium content relatively decreased. Moreover, there was no evident change in the wear and corrosion resistances due to the nickel contents.
\end{abstract}

Keywords: direct laser metal deposition; plasma nitriding; wear resistance; corrosion resistance

\section{Introduction}

Conventional nitriding for austenitic stainless steel is typically performed at treatment temperatures exceeding $500{ }^{\circ} \mathrm{C}$; this improves the surface hardness by synthesizing chromium or iron nitride. However, the formation of chromium nitride causes a reduction of the passive film on the stainless steel, thereby significantly deteriorating corrosion resistance. Therefore, it is difficult to apply conventional nitriding to austenitic stainless steels under corrosive environments. In contrast, low-temperature nitriding at treatment temperatures of less than $450{ }^{\circ} \mathrm{C}$ can form a supersaturated solid solution of nitrogen in the face-centered cubic lattice of austenitic stainless steel, which is known as the S-phase. The S-phase possesses a high hardness exceeding $1000 \mathrm{HV}$; it significantly enhances wear resistance. In addition, the S-phase does not disturb the formation of the passive film, because the S-phase is not a nitride. Therefore, the corrosion resistance is maintained after nitriding [1-23].

Low-temperature plasma nitriding can be applied to stainless steel plates and machinery parts. Recently, low-temperature plasma nitriding was also applied to the plasma-sprayed and cold-sprayed AISI 316L stainless steel coatings [24-27]. In addition, HVOF-sprayed stainless steel coatings were treated by gas nitriding and nitrocarburizing at low temperatures [28-30]. As results indicate, the low-temperature nitriding for these coatings produced the S-phase, thereby enhancing the wear resistance, similar to bulk austenitic stainless steels. In addition, the laser powder-bed fusion of AISI $316 \mathrm{~L}$ stainless steel was treated by low-temperature plasma nitriding, at the temperature of $430{ }^{\circ} \mathrm{C}$, and the wear and corrosion resistances were improved to the values of nitrided AISI 316L plates [31]. 
Ordinary austenitic stainless steels contain nickel as an alloy element. Nickel provides the crystal structure of stainless steel in an austenite phase (fcc lattice) and plays an important role in the formation of the S-phase. The effects of nickel on the formation and properties of the S-phase have been reported in several papers. For example, E. Menthe reported that the $S$ phase for nitriding can only be formed if iron, chromium, and nickel are available; however, the fcc structure of the austenite lattice is not necessary to form the S-phase [4]. On the contrary, J. Buhagiar reported that the S-phase can be produced in the surface of Ni-free ASTM F2581 austenitic stainless steel via low-temperature plasma nitriding at $430^{\circ} \mathrm{C}$. Accordingly, nickel is not essential for the formation of an S-phase in austenitic stainless steel [32]. F. Borgioli insisted that low-temperature glow-discharge nitriding can produce the S-phase without the formation of large amounts of nitrides, not only on AISI 316L and AISI 202 austenitic stainless steels but also on the nickel-free P558 alloy [33]. These studies examined the results by using stainless steels, which have a lower nickel content as compared with ordinary austenitic stainless steels. In addition, the results for increased nickel contents have not been reported. Recently, super stainless steels with high nickel contents are being widely used as corrosion-resistant materials for machinery parts. Therefore, the S-phase with high nickel austenitic stainless steels should be considered to further develop the low-temperature nitriding technique.

Direct laser metal deposition can synthesize the alloy layers by using several metal powders as the feeding powder. In this study, high-nickel austenitic stainless steel layers were deposited by using AISI 316L powder and nickel powder. Subsequently, these deposited alloy layers were processed by plasma nitriding at the temperature of $450{ }^{\circ} \mathrm{C}$ to produce the S-phase. Finally, the effects of nickel on the formation and properties (wear and corrosion resistance) of the S-phase were examined.

\section{Experimental Procedure}

\subsection{Direct Laser Metal Deposition}

Blended AISI 316L stainless steel and nickel powder were supplied as the feeding powder for direct laser metal deposition. The AISI 316L stainless steel powder has a diameter of $-212 /+63 \mu \mathrm{m}$, and the nickel powder has a diameter of $-150 /+45 \mu \mathrm{m}$. An AISI 304 stainless steel plate $\left(65 \times 65 \times 10 \mathrm{~mm}^{3}\right)$ was used as the substrate. Direct laser metal deposition was performed using a Laserline LDM-2000-60 machine (Laserline, $\mathrm{GmbH}$, Mulheim-Karlich, Germany). The laser beam was a continuous-wave diode laser with a wavelength of $940 \mathrm{~nm}$ and power of 1.2-1.4 kW. The feeding powder was delivered coaxially to the laser head (Fraunhofer, COAX12, Dresden, Germany) with mass flow rates of 13-14 g min ${ }^{-1}$, using an argon carrier gas. The laser head was scanned linearly to form one-layer depositions at traverse speeds of $4-5 \mathrm{~mm} \mathrm{~s}^{-1}$ and at intervals of $3 \mathrm{~mm}$. After the deposition, the stainless steel layers were polished to flatten and remove the surface layer. The final polishing was performed using metallographic $3 \mu \mathrm{m}$ diamond paste. After polishing, the thicknesses of the stainless steel layers exceeded $400 \mu \mathrm{m}$.

\subsection{Low-Temperature Plasma Nitriding}

Low-temperature plasma nitriding was treated using a laboratory-type DC plasma ion treatment machine (FECH-1N, Fuji Electronics Industry Co., Ltd., Osaka, Japan). The specimen was positioned on a holder in the chamber, and the cathode connected to the holder. The ratio of plasma gas was $\mathrm{N}_{2}: \mathrm{H}_{2}=80: 20$, at a flow rate of $1 \mathrm{~L} / \mathrm{min}$. The pressure in the chamber held at $667 \mathrm{~Pa}$. The nitriding temperature was $450^{\circ} \mathrm{C}$, and the treatment time was $4 \mathrm{~h}$.

\subsection{Characterization of the S-Phase}

X-ray diffraction measurements for the crystal structure of the stainless steel layers were carried out by conventional $\theta-2 \theta$ scans. Rigaku SmartLab (Tokyo, Japan) with $\mathrm{Cu}-\mathrm{K} \alpha$ radiation at $40 \mathrm{kV}$, and $150 \mathrm{~mA}$ was applied. 
Cross-sectional micrographs were obtained by using an optical microscope. Before the observations, samples were etched using Marble's reagent (containing $20 \mathrm{~mL} \mathrm{HCl}, 20 \mathrm{~mL} \mathrm{H}_{2} \mathrm{O}$, and $4 \mathrm{~g} \mathrm{CuSO}_{4}$ ). In addition, the thickness of the nitride layers was measured at approximately 80 points for each sample from the three cross-sectional micrographs.

The nitrogen depth distribution profiles were investigated by glow-discharge optical emission spectroscopy (GDOES) on the Rigaku GDA750 system (Tokyo, Japan).

The composition of the stainless steel layers was examined by SEM with energy-dispersive X-ray (EDX) analysis, SEM of Elionix ERA-8900FE, and EDX of AMETEK ApolloX, and the applied voltage of the SEM was $20 \mathrm{kV}$.

\subsection{Hardness and Wear Resistance}

The surface hardness of the stainless steel layers was measured using a Vickers tester (Mitutoyo HM-220D, Tokyo, Japan) with the test load of $0.245 \mathrm{~N}$; the tests were repeated six times. The amount of specific wear of the nitride layers was measured using a laboratory-type ball-on-disc reciprocal sliding wear tester, and it was carried out at temperatures of $19-21^{\circ} \mathrm{C}$ under dry conditions. For the tests, an $\mathrm{Al}_{2} \mathrm{O}_{3}$ ball (with a diameter of $4.76 \mathrm{~mm}$ ) on the sample was slid at a speed of $20 \mathrm{~mm} \cdot \mathrm{s}^{-1}$, frequency of $2 \mathrm{~Hz}$, amplitude of $5 \mathrm{~mm}$, and total sliding distance of $144 \mathrm{~m}$ with applying load of $1.96 \mathrm{~N}$. The wear test was repeated thrice for each sample. The cross-sectional area of the wear trails was measured using a roughness meter (Mitutoyo Formtracer CS-5000 (Mitutoyo, Tokyo, Japan)); the measurement was repeated thrice.

\subsection{Corrosion Resistance}

The corrosion resistance of the nitride layers was estimated by electrochemical polarization measurements. The electrochemical polarization measurements were performed using a potentiostat, HSV-110 (Hokuto Denko Corporation, Tokyo, Japan), with an Ag/AgCl reference electrode, and a platinum-plated counter electrode at a scan rate of $1 \mathrm{mV} \mathrm{s}^{-1}$. The experiments were carried out using 3.5 mass $\% \mathrm{NaCl}$ solution at a temperature of $30^{\circ} \mathrm{C}$. The $\mathrm{NaCl}$ solution was degassed by bubbling $\mathrm{N}_{2}$ gas for at least $0.5 \mathrm{~h}$ before the measurement, due to clear the influence of dissolved oxygen.

After the measurements, the surface morphologies were observed by an optical microscopy.

\section{Results and Discussion}

\subsection{Deposited Stainless Steel Layers}

The chemical compositions of the deposited stainless steel layers from EDX analysis are listed in Table 1. The nickel content of the AISI 316L layer was 11.4 mass $\%$. The nickel content of the stainless steel layers using AISI 316L and nickel powder were 14.7 mass $\%, 17.1 \mathrm{mass} \%, 21.8 \mathrm{mass} \%$, and 27.0 mass $\%$. The observations of the SEM-EDX mapping analysis revealed that nickel was dispersed uniformly in the stainless steel layers.

Table 1. Chemical composition of the deposited stainless steel layers (obtained using energy-dispersive X-ray (EDX)).

\begin{tabular}{ccccccc}
\hline \multirow{2}{*}{ Sample } & \multicolumn{6}{c}{ Chemical Composition (mass\%) } \\
\cline { 2 - 7 } & Si & Cr & Mn & Fe & Ni & Mo \\
\hline AISI 316L & 0.4 & 17.3 & 1.0 & 68.4 & 11.4 & 1.5 \\
Ni 14.7\% & 0.5 & 16.8 & 1.0 & 65.2 & 14.7 & 1.8 \\
Ni 17.1\% & 0.4 & 16.3 & 1.0 & 63.8 & 17.1 & 1.4 \\
Ni 21.8\% & 0.3 & 15.0 & 0.9 & 60.6 & 21.8 & 1.5 \\
Ni 27.0\% & 0.3 & 14.4 & 0.9 & 56.0 & 27.0 & 1.3 \\
\hline
\end{tabular}


Figure 1 shows the X-ray diffraction patterns of the stainless steel layers. The diffraction patterns of the high-nickel stainless steel layers were almost identical to those of the AISI 316L layer. Accordingly, the high-nickel stainless steel layers were in the austenite phase of the fcc lattice structure as the AISI 316L layer.

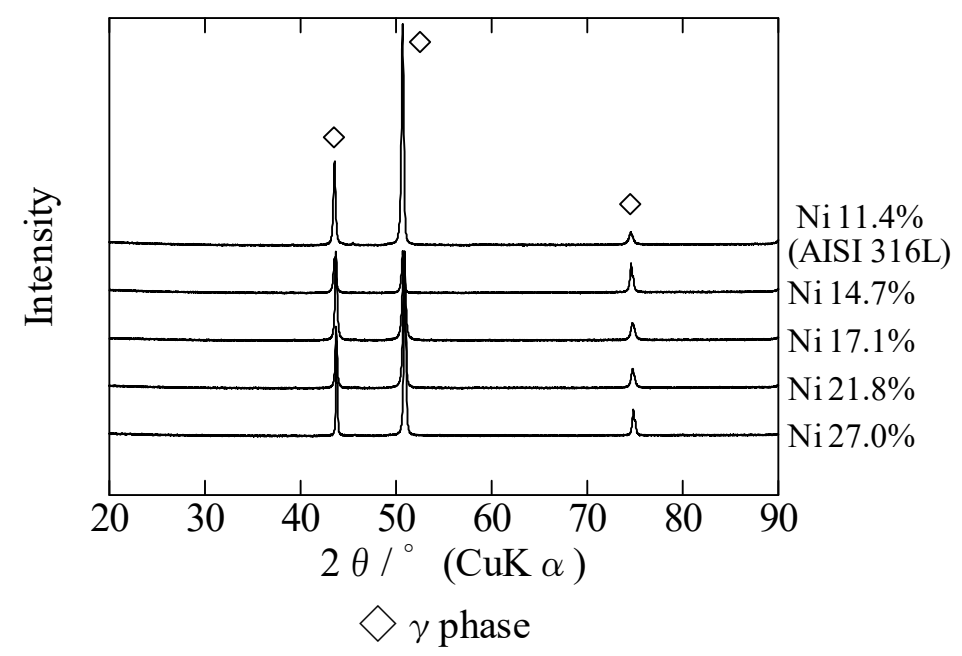

Figure 1. X-ray diffraction patterns of the as-deposited stainless steel layers with various nickel contents.

\subsection{Formation of S-Phase by Low-Temperature Plasma Nitriding}

After plasma nitriding at a temperature of $450{ }^{\circ} \mathrm{C}$, the XRD peaks for the (111) and (200) planes of the stainless steel layers shifted towards lower angles, as compared with the as-deposited stainless steel layers (Figure 2). This indicates that the lattice constants expanded due to the dissolution of nitrogen atoms. Generally, the formation of the S-phase is distinguished from austenitic stainless steel of an fcc lattice structure. The as-deposited stainless steel layers with high nickel content maintained an fcc lattice structure, as shown in Figure 1; therefore, the high-nickel stainless steel layers would also form the S-phase as the AISI 316L layer.

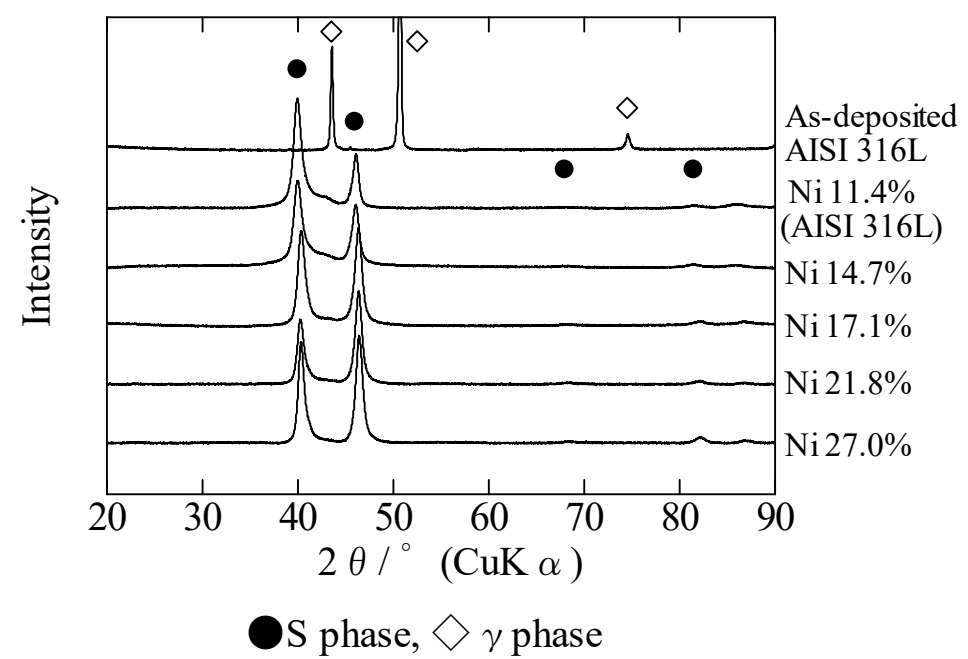

Figure 2. X-ray diffraction patterns of nitrided stainless steel layers with various nickel contents.

Figure 3 presents the overall views of the cross-section of the nitrided stainless steel layers. There are some pores in the deposited layers, and these porosities are $1.3 \%$ of $\mathrm{Ni} 11.4 \mathrm{mass} \%, 0.4 \%$ of $\mathrm{Ni}$ 14.7 mass $\%, 0.2 \%$ of $\mathrm{Ni} 17.1$ mass $\%, 0.5 \%$ of $\mathrm{Ni} 21.8$ mass $\%$, and $2.0 \%$ of $\mathrm{Ni} 27.0 \mathrm{mass} \%$. The pores were an inhomogeneous distribution, mostly part of the stainless steel layers was a dense microstructure as bulk steels. Figure 4 presents the S-phase layers on stainless steel layers by etching treatment. 
The S-phase layer appears as the lighter region at the surface. Figure 5 shows the thickness of the S-phase obtained by the measurements from the cross-sectional micrographs shown in Figure 4. The average thickness of the S-phase was in the range of 8.2-9.7 $\mu \mathrm{m}$; the increase in the thickness of the S-phase caused by the increase in the nickel content was estimated via the method of least squares.

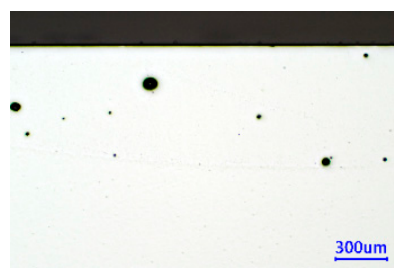

(a)

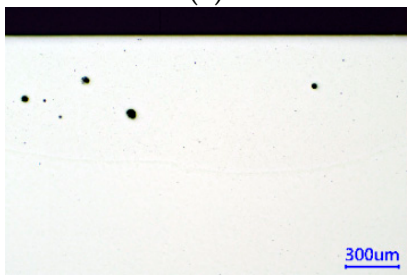

(d)

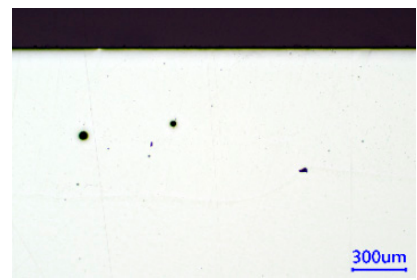

(b)

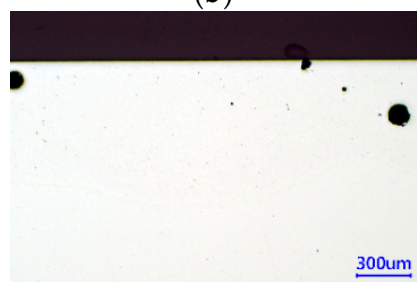

(e)

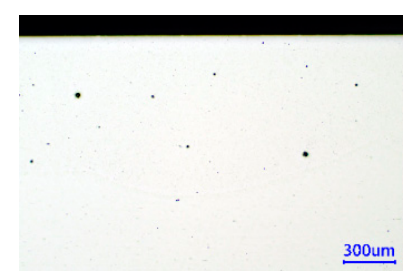

(c)

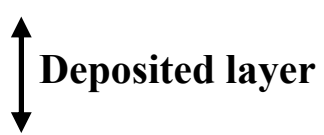

Figure 3. Cross-sectional micrographs of the stainless steel layers with various nickel contents: (a) 11.4 mass \%, (b) 14.7 mass $\%$, (c) 17.1 mass $\%$, (d) 21.8 mass $\%$, and (e) 27.0 mass $\%$.

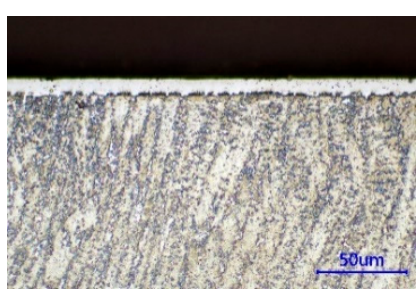

(a)

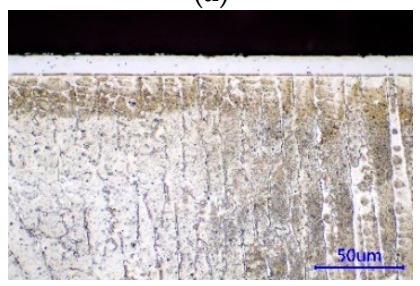

(d)

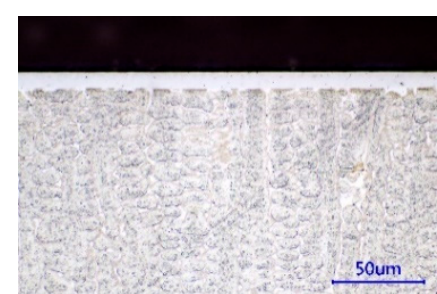

(b)

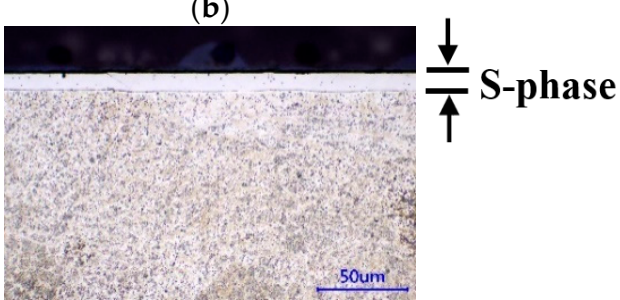

(e)

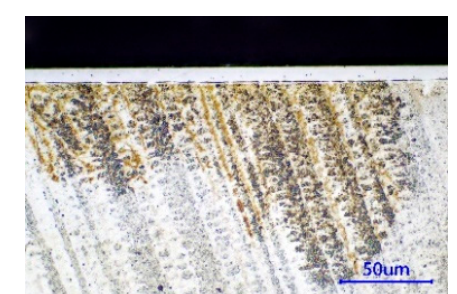

(c)

Figure 4. Cross-sectional micrographs of the S-phase layers on stainless steel layers with various nickel contents: (a) 11.4 mass \%, (b) 14.7 mass $\%$, (c) 17.1 mass $\%$, (d) 21.8 mass $\%$, and (e) 27.0 mass $\%$.

Figure 6 depicts the nitrogen depth distributions of the S-phase obtained via GDOES measurements. In addition, the nitrogen content errors of the GDOES were corrected based on the nitrogen content derived using Picard's equation (Equation (1)) with the XRD peak shifts as the average of the (111) and (200) planes in Figures 1 and 2. In Equation (1), $a_{\gamma n}$ is the expanded austenite lattice parameter, $a_{\gamma}$ is an austenite parameter of as-deposited stainless steels, $A$ is the Vegard's constant $(0.008 \AA$ per at\%) [34], and $C_{N}$ is the atomic nitrogen concentration in the S-phase layers.

$$
a_{\gamma \mathrm{n}}=a_{\gamma}+A C_{\mathrm{N}}
$$




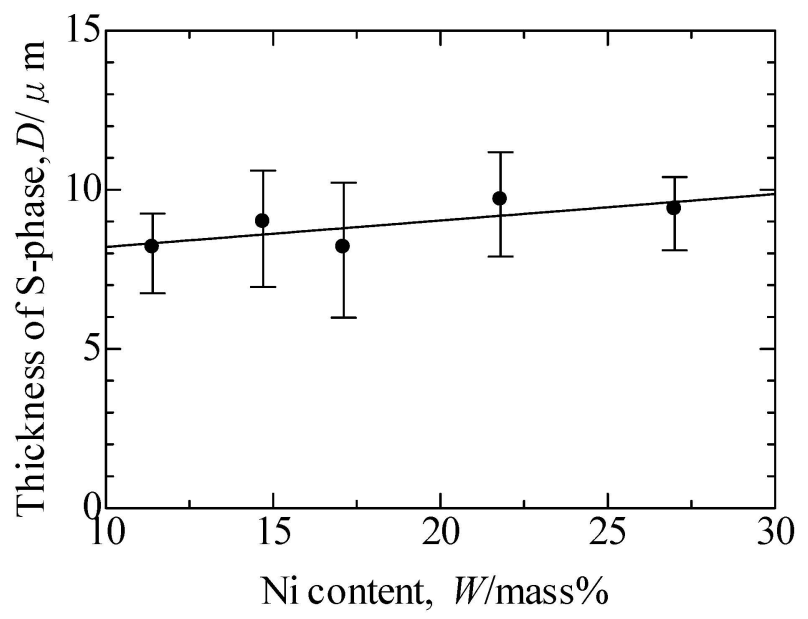

Figure 5. Thicknesses of the S-phase layers on stainless steel layers with various nickel contents.

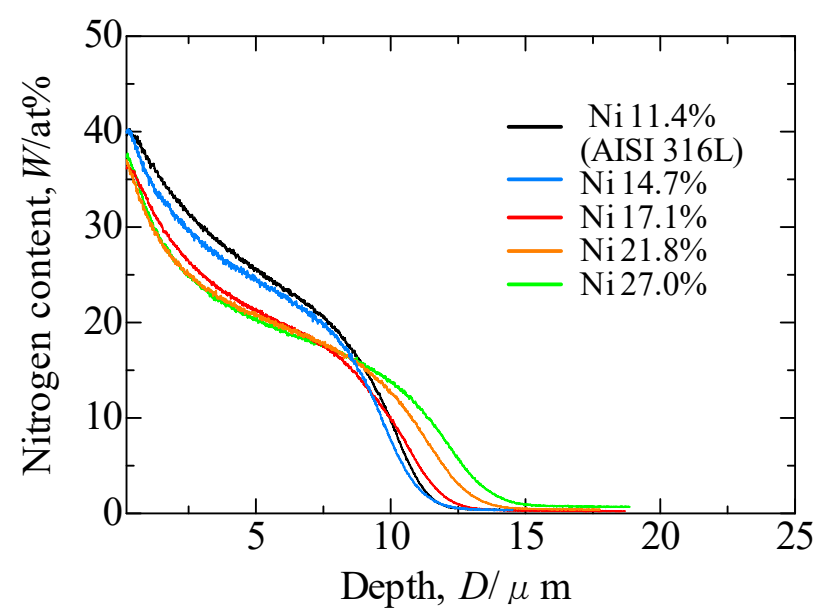

Figure 6. Nitrogen depth distributions of the S-phase layers with various nickel contents.

The nitrogen depth distributions in Figure 6 clearly indicate a plateau and step-like distribution rather than a smooth decreasing distribution. This plateau and step-like distribution has previously been reported with the affinity of chromium for nitrogen due to dissolved chromium atoms binding to nitrogen [35-37]. These chromium atoms trapping nitrogen play an important role in the formation of excessive nitrogen dissolved solid solution. The S-phase layers with the nickel content of 11.4 mass\% and 14.7 mass $\%$ stainless steels contain high nitrogen concentration under the depth of $8.5 \mu \mathrm{m}$, compared with the nickel content of 17.1 mass $\%, 21.8$ mass $\%$, and 27.0 mass $\%$ stainless steels. The chemical composition of the deposited stainless steel layers (Table 1) suggests that the increased nickel content caused a relative decrease in the chromium content. Therefore, the S-phase layers with the nickel content of 17.1 mass $\%, 21.8$ mass $\%$, and 27.0 mass $\%$ stainless steels contained less nitrogen due to the lower effect of the chromium atoms binding to nitrogen. On the contrary, the nitrogen in the nickel content of 17.1 mass $\%, 21.8$ mass $\%$, and 27.0 mass $\%$ stainless steels diffused to a deeper distance. The decreased chromium content in the stainless steel layers also promotes the nitrogen diffusion by less chromium atoms binding. Therefore nitrogen enables the diffusion of the inner layer; this leads to a thickening of the S-phase layers in the high-nickel stainless steels (Figure 5).

\subsection{Hardness and Wear Resistance}

The Vickers hardness of the S-phase and as-deposited stainless steel layers at the surface are shown in Figure 7. The as-deposited stainless steel layers had a hardness of 205-255 HV. In contrast, the hardness of the S-phase layers was 1103-1288 HV; hardness was considerably improved due to low-temperature plasma nitriding. In addition, the estimated hardness line obtained by the method 
of least squares decreased slightly with an increase in the nickel content. The nitrogen content at the surface of the S-phase layers decreased with an increase in the nickel content (Figure 6). Therefore, the effect of dissoluble nitrogen on the hardness improvement for the S-phase layers would diminish in the high-nickel stainless steel layers.

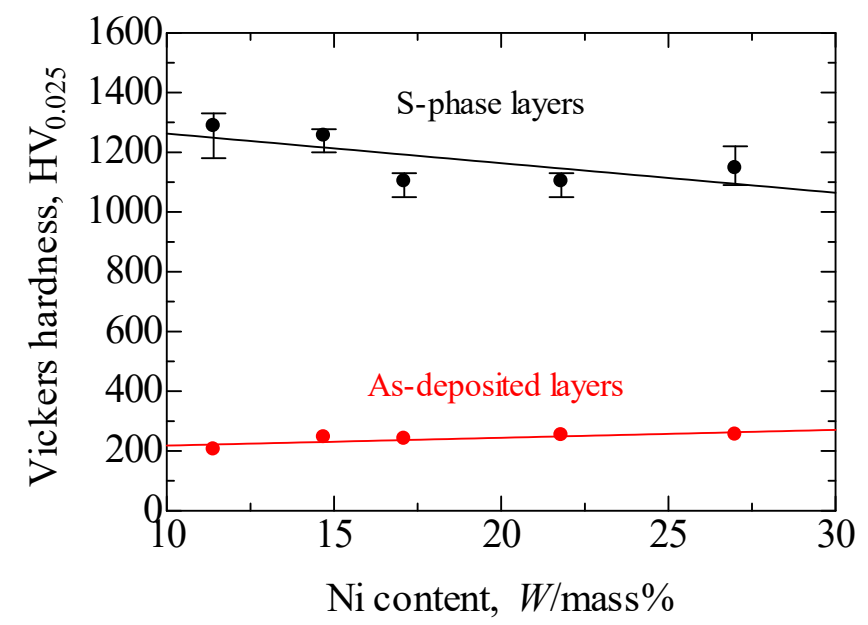

Figure 7. Hardness of the S-phase and as-deposited stainless steel layers with various nickel contents.

The specific wear is shown in Figure 8. The as-deposited AISI 316L layer was $1.4 \times 10^{-13} \mathrm{~m}^{2} \mathrm{~N}^{-1}$, and the S-phase layers were in the range of $0.8-2.5 \times 10^{-15} \mathrm{~m}^{2} \mathrm{~N}^{-1}$. Then, the low-temperature plasma nitriding improved the specific wear, reducing the abrasion by two orders of magnitude. The specific wear would exhibit the same degree regardless of any change in the nickel content.

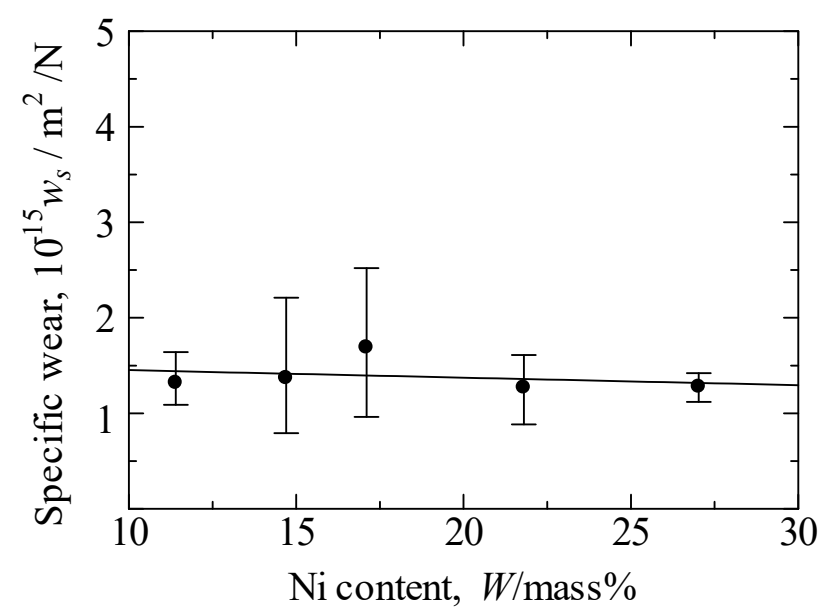

Figure 8. Specific wear of the S-phase layers with various nickel contents.

\subsection{Corrosion Resistance}

Figure 9 shows the anodic polarization curves of the S-phase and as-deposited AISI 316L layers. Table 2 lists the corrosion potential and current density. The Ni content of 11.4 mass $\%, 14.7$ mass $\%$, and 21.8 mass $\%$ are low of the corrosion current density compared with that of the as-deposited AISI 316L layer. On the contrary, the Ni content of $17.1 \mathrm{mass} \%$ are high current density, thus the S-phase layers would not invariably lead to reduce the corrosion current density. When the potential was over $0.4 \mathrm{~V}$, the current density of the as-deposited AISI 316L layer were much higher than those of the S-phase layers, indicating that the pitting corrosion was easily developed in the as-deposited AISI 316L layer. Figure 10 shows the surface morphologies after the anodic polarization measurement. The S-phase layers exhibited a negligible change in the discolored surface. In contrast, the as-deposited AISI 316L 
layer exhibited a severe pitting corrosion. In general, the effect of alloying elements on pitting resistance of various types of stainless steels reported that chromium, molybdenum and nitrogen strongly influence the pitting resistance equivalent numbers (PREN) as per Equation (2) [38]. In particular, the nitrogen content increases the PREN.

$$
\mathrm{PREN}=\% \mathrm{Cr}+3.3 \% \mathrm{Mo}+16 \% \mathrm{~N}
$$

Therefore, low-temperature plasma nitriding enhanced the pitting corrosion resistance ability of the deposited stainless steel layers by the S-phase formation, which is a solid solution of nitrogen. In addition, the anodic polarization curves of the S-phase layers did not exhibit definite correlations between the nickel content. Accordingly, stainless steels with higher nickel content than the AISI 316L did not improve the corrosion resistance of the S-phase.

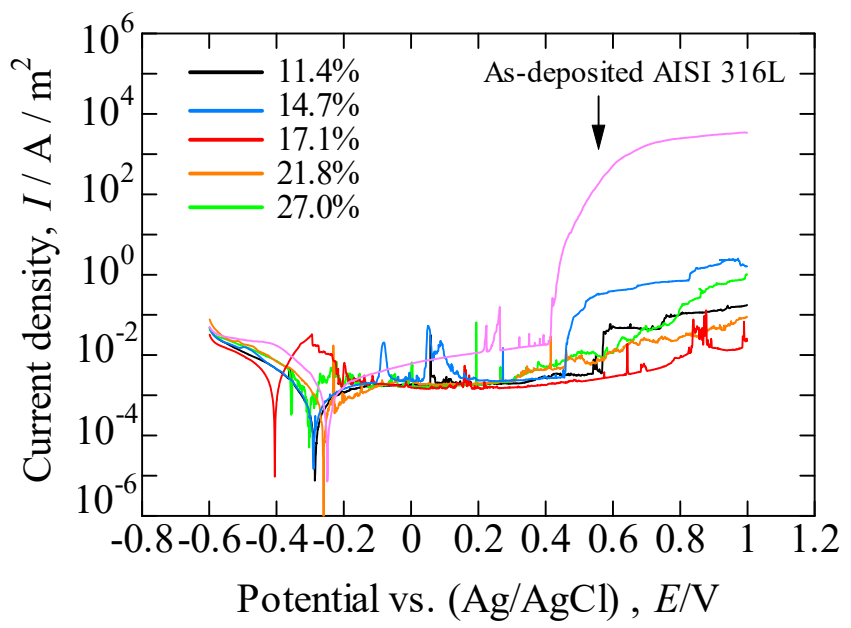

Figure 9. Anodic polarization curves in 3.5 mass $\% ~ N a C l$ solution of the S-phase and as-deposited AISI 316L layers with various nickel contents.

Table 2. Corrosion potential and current density in 3.5 mass $\% \mathrm{NaCl}$ solution of the S-phase and as-deposited AISI 316L layers with various nickel contents.

\begin{tabular}{ccc}
\hline \multirow{2}{*}{ Sample } & Corrosion Potential & Corrosion Current Density \\
\cline { 2 - 3 } & $\left.\boldsymbol{( E}_{\text {corr }} / \mathbf{V}\right)$ & $\left(\boldsymbol{I}_{\text {corr }} / \mathbf{A} / \mathbf{m}^{2}\right)$ \\
\hline Ni 11.4\% & -0.286 & $2.7 \times 10^{-4}$ \\
Ni $14.7 \%$ & -0.289 & $4.7 \times 10^{-4}$ \\
Ni 17.1\% & -0.405 & $2.4 \times 10^{-3}$ \\
Ni 21.8\% & -0.260 & $6.3 \times 10^{-4}$ \\
Ni 27.0\% & -0.303 & $1.1 \times 10^{-3}$ \\
As-deposited AISI 316L & -0.249 & $1.0 \times 10^{-3}$ \\
\hline
\end{tabular}

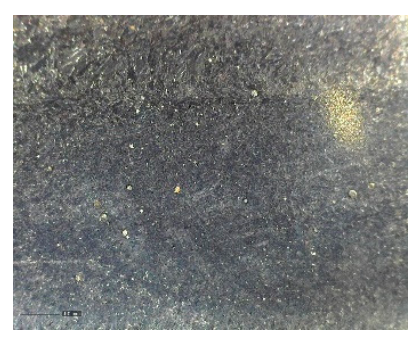

(a)

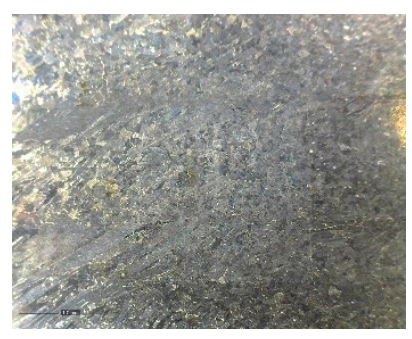

(b)

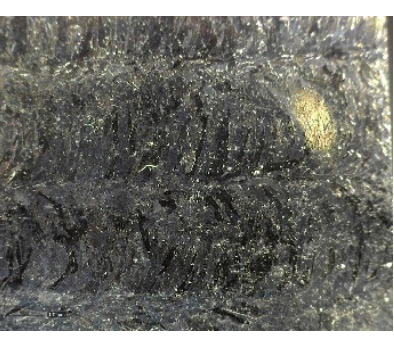

(c)

Figure 10. Cont. 


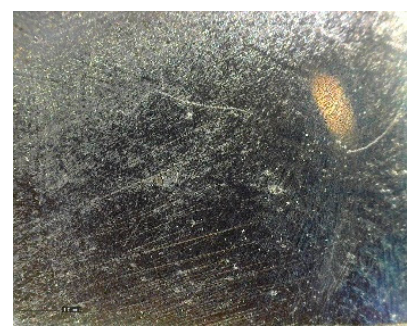

(d)

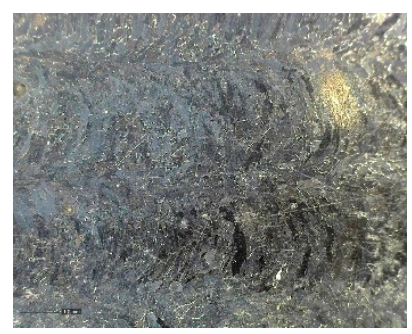

(e)

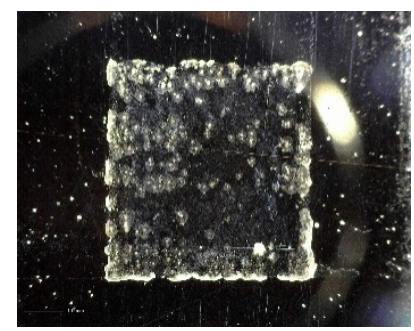

(f)

Figure 10. Surface morphology after anodic polarization measurements of the S-phase layers on stainless steel layers with various nickel contents: (a) 11.4 mass \%, (b) 14.7 mass \%, (c) 17.1 mass\%, (d) 21.8 mass \%, (e) 27.0 mass $\%$, and (f) as-deposited AISI 316L layer (not nitriding).

\section{Conclusions}

Austenitic stainless steel layers with different nickel contents (11.4 mass $\%, 14.7$ mass $\%, 17.1$ mass $\%$, 21.8 mass $\%$, and 27.0 mass $\%$ ) were treated using the direct laser metal deposition, and then by low-temperature plasma nitriding at a temperature of $450{ }^{\circ} \mathrm{C}$. As a result, the high-nickel stainless steel layers showed formation of the S-phase similar to the AISI 316L stainless steel layer. The thickness of the S-phase layers with high nickel content was more due to the weakening of the chromium atoms binding to nitrogen, thereby decreasing the chromium content relatively. The Vickers hardness of the S-phase layers was enhanced to 1103-1288 HV compared to the as-deposited stainless steel layers of 205-255 HV. The hardness decreased slightly with an increase in the nickel content owing to the decrease in the dissolved nitrogen. The specific wear of the S-phase layers also improved by two orders of magnitude. In addition, the anodic polarization curves suggested that the S-phase layers not reduce the corrosion current density invariably, but inhibit a pitting corrosion in $\mathrm{NaCl}$ solution. On the other hand, the wear and corrosion resistances were of the same degree regardless of any increase in nickel content. In conclusion, the low-temperature nitrided austenitic stainless steels, which alloyed higher nickel content compared with AISI 316L, enabled the formation of the S-phase, but had no effect on improving the wear and corrosion resistances. The increased nickel content in the stainless steel layers affects the decreasing chromium content relatively, and this decreasing chromium content increases the thickness of the S-phase layers.

Author Contributions: Conceptualization, S.A.; methodology, S.A.; investigation, S.A., M.E., T.Y., and N.U.; resources, S.A.; data curation, S.A.; formal analysis, S.A.; writing一original draft preparation, S.A.; writing-review and editing, S.A.; visualization, S.A.; supervision, S.A.; project administration, S.A.; funding acquisition, S.A. All authors have read and agreed to the published version of the manuscript.

Funding: This research was funded by KAKENHI, grant number 18K04792.

Conflicts of Interest: The authors declare no conflicts of interest.

\section{References}

1. Zhang, Z.L.; Bell, T. Structure and corrosion resistance of plasma nitride stainless steel. Surf. Eng. 1985, 1, 131-136. [CrossRef]

2. Ichii, K.; Fujimura, K.; Takase, T. Structure of the ion-nitrided layer of 18-8 stainless steel. Tech. Rep. Kansai Univ. 1986, 27, 135-144.

3. Saker, A.; Leroy, C.; Michel, H.; Frantz, C. Properties of sputtered stainless steel-nitrogen coatings and structural analogy with low temperature plasma nitrided layers of austenitic steels. Mater. Sci. Eng. A 1990, 140, 702-708. [CrossRef]

4. Menthe, E.; Rie, K.-T.; Schultze, J.W.; Simson, S. Structure and properties of plasma-nitrided stainless steel. Surf. Coat. Technol. 1995, 74, 412-416. [CrossRef]

5. Larisch, B.; Brusky, U.; Spies, H.-J. Plasma nitriding of stainless steels at low temperatures. Surf. Coat. Technol. 1999, 116, 205-211. [CrossRef] 
6. Sun, Y.; Li, X.Y.; Bell, T. X-ray diffraction characterization of low temperature plasma nitrided austenitic stainless steels. J. Mater. Sci. 1999, 34, 4793-4802. [CrossRef]

7. Liang, W.; Bin, X.; Zhiwei, Y.; Yaqin, S. The wear and corrosion properties of stainless steel nitrided by low-pressure plasma-arc source ion nitriding at low temperatures. Surf. Coat. Technol. 2000, 130, 304-308. [CrossRef]

8. Baranowska, J. Characteristic of the nitride layers on the stainless steel at low temperature. Surf. Coat. Technol. 2004, 180, 145-149. [CrossRef]

9. Mingolo, N.; Tschiptschin, A.P.; Pinedo, C.E. On the formation of expanded austenite during plasma nitriding of an AISI 316L austenitic stainless steel. Surf. Coat. Technol. 2006, 201, 4215-4218. [CrossRef]

10. Gontijo, L.C.; Machado, R.; Miola, E.J.; Casteletti, L.C.; Alcantara, N.G.; Nascente, P.A.P. Study of the $S$ phase formed on plasma-nitrided AISI 316L stainless steel. Mater. Sci. Eng. A 2006, 431, 315-321. [CrossRef]

11. Hamdy, A.S.; Marx, B.; Butt, D. Corrosion behavior of nitride layer obtained on AISI 316L stainless steel via simple direct nitridation route at low temperature. Mater. Chem. Phys. 2011, 126, 507-514. [CrossRef]

12. Chemkhi, M.; Retraint, D.; Roos, A.; Garnier, C.; Waltz, L.; Demangel, C.; Proust, G. The effect of surface mechanical attrition treatment on low temperature plasma nitriding of an austenitic stainless steel. Surf. Coat. Technol. 2013, 221, 191-195. [CrossRef]

13. Köster, K.; Kaestner, P.; Bräuer, G.; Hoche, H.; Troßmann, T.; Oechsner, M. Material condition tailored to plasma nitriding process for ensuring corrosion and wear resistance of austenitic stainless steel. Surf. Coat. Technol. 2013, 228, S615-S618. [CrossRef]

14. Christiansen, T.L.; Drouet, M.; Martinavičius, A.; Somers, M.A.J. Isotope exchange investigation of nitrogen redistribution in expanded austenite. Scr. Mater. 2013, 69, 582-585. [CrossRef]

15. Stinville, J.C.; Cormier, J.; Templier, C.; Villechaise, P. Monotonic mechanical properties of plasma nitrided 316L polycrystalline austenitic stainless steel: Mechanical behavior of the nitrided layer and impact of nitriding residual stresses. Mater. Sci. Eng. A 2014, 605, 51-58. [CrossRef]

16. Borgioli, F.; Galvanetto, E.; Bacci, T. Low temperature nitriding of AISI 300 and 200 series austenitic stainless steels. Vacuum 2016, 127, 51-60. [CrossRef]

17. Zhao, G.-H.; Aune, R.E.; Espallargas, N. Tribocorrosion studies of metallic biomaterials: The effect of plasma nitriding and DLC surface modifications. J. Mech. Behav. Biomed. Mater. 2016, 63, 100-114. [CrossRef]

18. Yang, W.J.; Zhang, M.; Zhao, Y.H.; Shen, M.L.; Lei, H.; Xu, L.; Xiao, J.Q.; Gong, J.; Yu, B.H.; Sun, C. Enhancement of mechanical property and corrosion resistance of $316 \mathrm{~L}$ stainless steels by low temperature arc plasma nitriding. Surf. Coat. Technol. 2016, 298, 64-72. [CrossRef]

19. Lu, S.; Zhao, X.; Wang, S.; Li, J.; Wei, W.; Hu, J. Performance enhancement by plasma nitriding at low gas pressure for 304 austenitic stainless steel. Vacuum. 2017, 14, 334-339. [CrossRef]

20. Zhang, X.; Wang, J.; Fan, H.; Pan, D. Erosion-corrosion resistance properties of 316L austenitic stainless steels after low-temperature liquid nitriding. Appl. Surf. Sci. 2018, 440, 755-762. [CrossRef]

21. Borgioli, F.; Galvanetto, E.; Bacci, T. Surface modification of austenitic stainless steel by means of low pressure glow-discharge treatments with nitrogen. Coatings 2019, 9, 604-614.

22. Borgioli, F.; Galvanetto, E.; Bacci, T. Effects of surface modification by means of low temperature plasma nitriding on wetting behavior of austenitic stainless steel. Coatings 2020, 10, 98. [CrossRef]

23. Borgioli, F. From austenitic stainless steel to expanded austenite-S phase: Formation, characteristics and properties of an elusive metastable phase. Metals 2020, 10, 187. [CrossRef]

24. Adachi, S.; Ueda, N. Formation of S-phase layer on plasma sprayed AISI 316L stainless steel coating by plasma nitriding at low temperature. Thin Solid Films 2012, 523, 11-14. [CrossRef]

25. Adachi, S.; Ueda, N. Combined plasma carburizing and nitriding of sprayed AISI 316L steel coating for improved wear resistance. Surf. Coat. Technol. 2014, 259, 44-49. [CrossRef]

26. Adachi, S.; Ueda, N. Formation of expanded austenite on a cold-sprayed AISI 316L coating by low-temperature plasma nitriding. J. Therm. Spray Technol. 2015, 24, 1399-1407. [CrossRef]

27. Adachi, S.; Ueda, N. Wear and Corrosion Properties of cold-sprayed AISI 316L coatings treated by combined plasma carburizing and nitriding at low temperature. Coatings 2018, 8, 456. [CrossRef]

28. Lindner, T.; Mehner, T.; Lampke, T. Surface modification of austenitic thermal-spray coatings by low-temperature nitrocarburizing. IOP Conf. Series Mater. Sci. Eng. 2016, 118, 012008. [CrossRef]

29. Lindner, T.; Kutschmann, P.; Löbel, M.; Lampke, T. Hardening of HVOF-sprayed austenitic stainless-steel coatings by gas nitriding. Coatings 2018, 8, 348. [CrossRef] 
30. Kutschmann, P.; Lindner, T.; Börner, K.; Reese, U.; Lampke, T. Effect of adjusted gas nitriding parameters on microstructure and wear resistance of HVOF-sprayed AISI 316L coatings. Materials 2019, 12, 1760. [CrossRef]

31. Godec, M.; Donik, Č.; Kocijan, A.; Podgornik, B.; Skobir Balantič, D.A. Effect of post-treated low-temperature plasma nitriding on the wear and corrosion resistance of $316 \mathrm{~L}$ stainless steel manufactured by laser powder-bed fusion. Addit. Manuf. 2020, 32, 101000-101008. [CrossRef]

32. Buhagiar, J.; Li, X.; Dong, H. Formation and microstructural characterisation of S-phase layers in Ni-free austenitic stainless steels by low-temperature plasma surface alloying. Surf. Coat. Technol. 2009, 204, 330-335. [CrossRef]

33. Borgioli, F.; Galvanetto, E.; Bacci, T. Corrosion behaviour of low temperature nitrided nickel-free, AISI 200 and AISI 300 series austenitic stainless steels in $\mathrm{NaCl}$ solution. Corros. Sci. 2018, 136, 352-365. [CrossRef]

34. Cheng, L.; Bottger, A.; de Keijser, T.H.; Mitterneijer, E.J. Lattice parameters of iron-carbon and iron-nitrogen martensites and austenites. Scripta Metall. Mater. 1990, 24, 509-514. [CrossRef]

35. Moller, W.; Parascandola, S.; Telbizova, T.; Gunzel, R.; Richter, E. Surface processes and diffusion mechanisms of ion nitriding of stainless steel and aluminium. Surf. Coat. Technol. 2001, 136, 73-79. [CrossRef]

36. Riviere, J.P.; Meheust, P.; Villain, J.P.; Templier, C.; Cahoreau, M.; Abrasonis, G.; Pranevicius, L. High current density nitrogen implantation of an austenitic stainless steel. Surf. Coat. Technol. 2002, 158-159, 99-104. [CrossRef]

37. Czerwiec, T.; Andrieux, A.; Marcos, G.; Michel, H.; Bauer, P. Is "expanded austenite" really a solid solution? Mossbauer observation of an annealed AISI 316L nitrided sample. J. Alloys Compd. 2019, 811, 151972-151983. [CrossRef]

38. Garfias-Mesias, L.F.; Sykes, J.M.; Tuck, C.D.S. The effect of phase compositions on the pitting corrosion of 25 cr duplex stainless steel in chloride solutions. Corros. Sci. 1996, 38, 1319-1330. [CrossRef]

(C) 2020 by the authors. Licensee MDPI, Basel, Switzerland. This article is an open access article distributed under the terms and conditions of the Creative Commons Attribution (CC BY) license (http://creativecommons.org/licenses/by/4.0/). 